\title{
Musicality Development on the Teaching of Musical Arts to Children of 6 to 9 Years Old
}

\author{
Trisakti \\ Universitas Negeri Surabaya \\ Surabaya, Indonesia \\ trisakti@unesa.ac.id
}

\author{
Setyo Yanuartuti \\ Universitas Negeri Surabaya \\ Surabaya, Indonesia \\ setyoyanuartuti@unesa.ac.id
}

\author{
Yulisetiana \\ Universitas Negeri Surabaya \\ Surabaya, Indonesia \\ Yulisetiana73@yahoo.com
}

\begin{abstract}
The teaching and learning process of music arts for children from ages 6 to 9 years old needs a careful strategy in its implementation. A case in a course Accento Music Education Centre Surabaya shows the lack of musicality of children that causes their learning outcomes to be less optimal. In its teaching and learning process, the teachers only emphasize on the practical learning using musical instruments, thus, the musicality elements cannot be fulfilled optimally. This descriptive qualitative research aims to investigate the primary and secondary data using observation, interview, and documentation as the data collection techniques. The data analysis is conducted through some stages of data reduction, data presentation, and conclusion drawing. On the other hand, the researcher uses data triangulation which purpose is to examine the validity of the data through source triangulation, triangulation of data collection technique, and triangulation of time. The results of the study found that the use of teaching media in the form of course book completed with CD MP3 can be implemented to achieve the objectives of the study in order to develop children's musicality. The teaching and learning process using this strategy starts with introducing rhythm and intonation by singing and playing musical instruments. Using musical course books with CD MP3 can also develop the musicality of children through three indicators, namely singing in a right pitch, expressing songs, following the rhyme by clapping.
\end{abstract}

\section{Keywords - teaching and learning; musical arts; musicality}

\section{INTRODUCTION}

The implementation of music arts education can be carried out in both formal and non-formal education. In formal education, music arts education is implemented through the subject of Arts and Culture in both primary and secondary education based on the curriculum set by the government. Meanwhile, in non-formal education, music arts education is implemented by only few schools which focus is specifically on music, and also by music studios or courses.

The implementation of music arts education in conservatories for children at the age of 6 to 9 years old has a tendency to equip children with a potential in playing musical instruments. Djohan [1] states that the ability of children in mastering musical instruments has become an emphasis on the teaching and learning music nowadays. Children tend to have a skill in playing musical instruments, while the natural ability in musicality that they have brought since birth is not wellsupported.

According to Jelia [2], at the age of 6 to 9 years old, children's fine motor begins to develop, which is considered as a suitable stage for them to learn music arts. Those children also have a sharp memory to memorize things faster, especially when it comes to learning music. Harris and Crozier [3] explains that the age of 6 to 9 years old is the perfect age for children to acquire music arts education because of the great memorizing skills and high motivation they have, even though they are still hard to concentrate. They have an ability to read symbols that appears surrounding them by focusing their attention on the objects around. Their thinking process to see the authentic phenomenon is still logic, it helps them to learn that phenomenon. Furthermore, they learn new thing through their attention, even though they do not fully focus on that phenomenon, their learning showed that they can correlate one aspect to other aspect. It occurs in the way children learn music, they have not have ability to fully focus on music but they are able to follow their lesson well.

Accento Music Education Centre is a non-formal institution which concern is specifically on music arts education. It provides a teaching and learning of music program for children from 6 to 9 years old. Early observation shows that children are still lack of musicality, which is shown by fals pitch found when they are singing, lack of knowledge in terms of tone when they are asked to clap in accordance with the rhythm, and lack of knowledge in tempo when they are playing music. The ability in musicality determines the success of children in learning music. Jelia [2] argues that in developing musicality, children should learn first about rhyme, rhythm, and tempo. The development of children's musicality can be implemented by teaching them proper music arts teaching material. It can be in a form of a musical course book that is used for children to 
practice music arts so that they will experience the musicality by themselves. A musical course book that is supported with a suitable teaching media will give positive impact for the development of children's musicality.

Based on the research background explained earlier, this study aims to elaborate the teaching of music arts using a specific musical course book for children at the age of 6 to 9 years old, and to describe the development of children's musicality by using the musical course book that is equipped with the teaching media.

\section{METHODS}

This study is a qualitative descriptive research. The sources of the data are divided into primary and secondary data. The primary data is acquired through observation of teaching and learning process of music arts in Accento Music Education Centre Surabaya, and interview of the teachers and the children of 6 to 9 years old that belongs to study music there. According to Arikunto [4], the data collection technique using observation is conducted using all five senses or, in other words, direct observation. It is a suitable technique to be used in this research which goal is to observe the teaching and learning process of the children. The interview technique in collecting the primary data is in line with Sugiono's [5] concept that interview is one of the collection techniques which aim is to examine the research problems in order to get the detail results. As for the secondary data, it is carried out using documentation technique from the report of students' learning outcomes in a form of score or achievement and the report of students' musicality development. The data analysis of this study is using the concept of Miles and Hubermas [6] that is divided into three stages, namely data reduction, data presentation, and conclusion drawing. Furthermore, the researcher uses data triangulation which purpose is to examine the validity of the data through source triangulation, triangulation of data collection technique, and triangulation of time [5]. Source triangulation in this study is used by checking the validity of the data from the data sources. Triangulation of data collection technique is acquired by examining the data from the observation, interview, and documentation. Meanwhile, the triangulation of time is conducted by observing and interviewing in different time, but the having same results.

\section{RESULTS AND DISCUSSION}

\section{A. The Teaching of Musical Arts}

Music arts education is suitable to be implemented when children are at their age of 6 to 9 years old. It is because, at their age, they start to develop their motor and have the ability to memorize well even though they are still hard to concentrate. Children's curiosity is also one of the factors to achieving the learning outcomes. According to Harris and Richard [3], despite the lack of ability to concentrate well, children at the age of 6 to 9 years old have a great sense of curiosity that will be impactful for them to learn music arts in an easy way. In line with this opinion, Jelia [2] states that children's curiosity on particular matters can also trigger their creativity.
Music art has an important role to children's development. They will be actively engaged in music arts to develop their creativity, sensitivity, sense of beauty, ability in music, discipline, and insights on culture [7]. The developing of children's creativity could be done by expressing themselves through musical art. The musical art activities include sing a song and play the simple art instruments. Then, the children's sensitivity in music could be seen through their sensitivity in hearing the tone. By hearing the tone, they will easy to feel the appropriate tones that they sing and play using the instruments. Then, the aesthetic feeling in music will appears when they express the song and playing the music instruments. In other words, they are easy to express their aesthetic feeling through their expression when they sing a song and play the music instrument. Furthermore, playing music also increases their discipline because playing music need their persistence which improve their discipline to gain the great results. In results, when they have a great discipline, the appropriate tone, rhythm, and message of the song will produce perfectly. In other words, learning music arts will grow a sense of arts inside them and sensitivity towards their surroundings.

The teaching of music arts in non-formal institution Accento Music Education Centre Surabaya uses a teaching media as stimuli for children to achieve the learning objectives. The teaching media used is in the form of a musical course book equipped with CD MP3 that has certain back songs for children to imitate by singing or playing musical instruments to gain a good musicality. The concept of stimuli through this teaching media will result a good positive response from children through tone imitation that they do repeatedly as practice. This behavioristic approach is appropriate to be implemented when it comes to teach music arts. Andriyani [8] explains that studying needs an input such as stimuli, and an output in a form of response. Despite the urgency of teaching media as a stimulus, teacher's role is also important in the teaching and learning process. Teacher can introduce them rhythm in songs by clapping, while students at the same time pay attention thoughtfully and imitate the clapping. Teacher can also teach them intonation by singing and students need to imitate it. Furthermore, in teaching how to play musical instruments, teacher needs to give an example on how to play them properly while students imitate it.

The course book of musicality completed with CD MP3 that is designed by the teachers in preparing the teaching and learning process has an objective to facilitate the children in learning music. There are thirteen parts of the teaching materials that have been coherently arranged in the book. The materials are namely: (1) the differences between high and low pitch (2) introduction to G and F chord (3) sharp or flat key to find $C$ (4) notation and rest or silent signs (5) playing songs using $\mathrm{C}$ note following the rhyme (6) playing songs using $\mathrm{D}$ note following the rhyme (7) sharp or flat key to find $F(8)$ playing songs using E note (9) notation not and full sign (10) the black emphasizing on the keyboard to find F location, (11) playing songs using F not (12) playing songs using G not, and (13) learning notation three as counting. 


\section{B. The Development of Children's Musicality}

The musical intelligence of children is obtained since birth [3]. In line with this argument, Sumaryanto [9] concludes that the music ability is an innate ability that is attached to each individual as it is proven by responses given to particular musical components such as rhythm, melody, and harmony. Siregar and Nara [10] explains that the main characteristic of musical intelligence of children is the ability to absorb, appreciate, and create rhyme or melody. The musical intelligence the children have can grow a feeling of sensitivity towards tone so that they can accurately keep up with the rhyme of the music through their ability to hear. The music ability is defined as an innate ability of individuals that covers the melody ability which is the ability to sing with proper pitch, the ability to adjust the rhyme while singing, and the harmony ability that make children sensitive to musical masterpieces.

The teaching and learning process in Accento Music Education Centre (AMEC) Surabaya starts with the pre-test to find out the musical ability of the children. This pre-test consists of three indicators of assessment, namely singing with the right pitch, expressing the songs, and following the rhyme by clapping. The result of the pre-test carried out on ten students of AMEC found that the music ability of children is still $67 \%$ less than optimal. Not only pre-test, but post-test is also conducted by the end of the teaching process that uses a musical course book. This post-test has a goal which is to examine the learning outcomes. Students are asked to sing properly in the right pitch, to express the songs they sing, and to clap following the rhyme of the songs. The result of the posttest shows the development on the musicality of children from $67 \%$ to $93.3 \%$.

The development of children's musicality in Accento Music Education Centre Surabaya using a musical course book that is equipped with CD MP3 is listed as follows.

a. Children are able to sing with the right melody

b. Children are able to adjust the rhyme while singing songs

c. Children are able to notice that they produce discordant pitch while singing

d. Children are able to know that their friends produce discordant pitch while singing

e. Children are able to express the songs they sing

f. Children are getting happier and more interested in listening to music

g. Children are able to play musical instruments

h. Children have a great desire to always be involved in music

i. Children has an ability to memorize songs well

j. Children are able to keep up easily with rhyme by using simple percussion instruments k. Children are able to recognize tone or pitch of various songs or music

1. Children are able to keep up easily with the rhyme of songs or music

\section{CONCLUSION}

Music arts education for children at the age of 6 to 9 years old in Accento Music Education Centre Surabaya using teaching media as stimulus can develop the children's musicality. The teaching media used is a musical course book equipped with CD MP3 that has thirteen parts of the teaching materials. Those are (1) the differences between high and low pitch (2) introduction to G and F chord (3) sharp or flat key to find $\mathrm{C}$ (4) notation and rest or silent signs (5) playing songs using $\mathrm{C}$ note following the rhyme (6) playing songs using D note following the rhyme (7) sharp or flat key to find F (8) playing songs using E note (9) notation not and full sign (10) the black emphasizing on the keyboard to find $\mathrm{F}$ location, (11) playing songs using F not (12) playing songs using $\mathrm{G}$ not, and (13) learning notation three as counting. The teachers start the teaching and learning process by introducing rhythm through clapping, teaching intonation by singing, and playing music, while all the children imitate them.

The development of children's musicality by using a musical course book and a teaching media is assessed by using three indicators, namely singing in the right pitch, expressing songs, and following the rhyme by clapping.

\section{REFERENCES}

[1] Djohan, Musical Ability As a Mean of Development of Social Skills. Jurnal Penelitian dan Evaluasi Pendidikan, 12 (1), pp. 111-129, 2009.

[2] M.H. Jelia, Pengetahuan Dasar Musik Teori. Jakarta: Pustaka Muda, 2016.

[3] R. Crozier and P. Harris, The Music Teacher's Companion. United Kingdom: Faber Music, Ltd, 2006.

[4] S. Arikunto, Prosedur Penelitian Suatu Pendekatan Praktek. Jakarta: PT. Rineka Cipta, 1998.

[5] Sugiyono, Penelitian Kuantitatif Kualitatif dan R\&D. Bandung: Alfabeta, 2010.

6] M. Miles and M. Huberman, Analisis Data Kualitatif. Jakarta: Universitas Indonesia Press, 1992.

[7] S. Rien, Pendidikan Seni Musik. Jakarta: Depdikbud, 1999.

[8] F. Andriyani, Teori Belajar Behavioristik dan Pandangan Islam tentang Behavioristik. Jurnal Pendidikan dan Pranata Islam, 10 (2), pp. 165-180, 2005.

[9] T. Sumaryanto, Kemampuan Musikal (Music Ability) dan Pengaruhnya Terhadap Prestasi Belajar Musik. Journal of Arts Research and Education, 1 (1), 2011.

[10] E. Siregar and H. Nara, Teori Belajar dan Pembelajaran. Bogor: Ghalia Indonesia, 2010 